\title{
PENINGKATAN KEMAMPUAN MEMORI ANAK PADA KONSEP ANGKA MELALUI PERMAINAN ULAR TANGGA
}

\author{
Dhita Paranita Ningtyas \\ Universitas Trilogi Jakarta \\ E-mail :dhita@trilogi.ac.id
}

\section{Article received: 26 Juli 2018, Review process: 04 Agustus 2018 \\ Article published: 30 September 2018}

\begin{abstract}
Calistung's learning is not a difficult lesson for early childhood, but its recognition to children must be in the right way so that children can know and understand well. Researchers do research Improvement of memory on the concept of numbers in children Group A in BKB Mawar Jakarta is aimed to improve the memory capacity of children aged 4-5 years in learning to know the concept of numbers dipembelajaran early school entrance. So when the child understands correctly and in a fun way the child can more quickly remember and stored in the child's memory. This research uses "Action Research" research method with 2 implementation cycles. The results of this study are expected with this modified snake ladder game can improve the child's memory on the concept of numbers so that children can understand well about the basics of mathematics learning.
\end{abstract}

Keywords: Kids Memory Capabilities, Draft Numbers, Snake Game Ladder

\begin{abstract}
Abstrak
Pembelajaran Calistung bukanlah pembelajaran yang susah untuk anak usia dini, akan tetapi pengenalannya kepada anak harus dengan cara yang tepat sehingga anak dapat mengenal dan memahami dengan baik. Peneliti melakukan penelitian Peningkatan memori pada konsep angka pada anak Kelompok A di BKB Mawar Jakarta ini bertujuan untuk meningkatkan kemampuan memori anak usia 4-5 tahun dalam pembelajaran mengenal konsep angka dipembelajaran awal masuk sekolah. Sehingga apabila anak memahami dengan benar dan dengan cara yang menyenangkan anak dapat lebih cepat mengingat dan tersimpan dalam memori anak tersebut. Penilitian ini menggunakan metode penelitian "Action Research" dengan 2 siklus pelaksanaan. Hasil dari penelitian ini diharapkan dengan permainan ular tangga yang telah dimodifikasi ini dapat meningkatkan memori anak pada konsep angka sehingga anak dapat memahami dengan baik tentang dasar dari pembelajaran matematika.
\end{abstract}

Kata Kunci: Kemampuan Memori Anak, Konsep Angka, Permainan Ular Tangga.

\section{PENDAHULUAN}

Pendidikan Anak Usia Dini merupakan pendidikan awal untuk anak, dimana semua aspek perkembangan anak berkembang secara maksimal di usia Golden Age. Pada Usia ini anak dapat menerima informasi dengan baik, sehingga diperlukan stimulus-stimulus untuk meningkatkan kemampuan 6 aspek perkembangan anak, yaitu aspek sosial emosional, aspek 
moral dan agama, aspek kognitif, aspek bahasa aspek fisik motorik, dan aspek seni. Pada masa ini pemberian stimulus yang tepat sangatlah penting. Menurut hasil penelitian di bidang neurologi yang disampaikan oleh Aisah, perkembangan otak anak tumbuh pesat di usia dini. Salah satu hasil penelitian yang penting dicatat, pada usia empat tahun kapasitas kecerdasan anak mencapai 50 persen dan delapan tahun mencapai 80 persen.

Menurut Eric Jansen ada banyak cara untuk mengklasifikasikan memori, misalnya memori jangka pendek, jangka panjang, deklaratif, nondeklaratif, refleksif, prosedural dan otak berhubungan dengan masing-masing dari semua hal ini dengan cara yang berbeda-beda. Otak manusia menyortir dan menyimpan informasi berdasarkan apakah informasi itu melekat kuat dalam konteks atau dalam muatan. Sehingga memori pada anak usia dini jarang dibentuk melalui ketidaksengajaan, karena anak usia dini hanya mengingat kejadian yang menurut anak tersebut berkesan kuat bagi anak.

Hasil penelitian yang telah dilakukan oleh peneliti di anak kelompok A BKB Mawar Kalibata diperoleh hasil awal penelitian tentang bagaimana anak dapat mengingat konsep angka 1-10 dilakukan observasi awal dan diperoleh data bahwa, a) kemampuan anak dalam mengingat angka belum maksimal terlihat dari lebih dari 12 anak tidak tercapainya indikator anak mampu mengulang kembali angka 1-10 dengan urut, b) anak tidak mampu menyebutkan angka apabila ditunjuk secara acak, c) anak menyukai angka dengan warna yang lebih menarik, d) anak tidak akan mengingat lebih lama apabila tidak diulang-ulang dalam pengenalan angka tersebut, e) guru hanya mengenalkan angka dari tulisan di papan tulis sehingga media yang digunakan kurang menarik. Dari hasil penelitian tahap awal tersebut peneliti merancang membuat media untuk mengenalkan konsep angka untuk anak usia dini melalui permainan ular tangga.

Dari penelitian ini peneliti merumuskan masalah diantaranya adalah, apakah dengan penelitian "Peningkatan Kemampuan Memori Anak Pada Konsep Angka Melalui Permainan Ular Tangga" dapat meningkatkan kemampuan anak dalam meningkatkan memori pada konsep angka dan bagaimana cara permainan ular tangga dapat meningkatkan kemampuan meningkatkan memori pada konsep angka pada anak usia dini.

\section{KONSEP MEMORI}

Memori yang dimiliki manusia memiliki jenis-jenis dan fungsinya masing-masing. 
Penyimpanan memori menurut (Santrock, 32:2009) melibatkan tiga jenis memori dengan kerangka waktu yang berbeda: memori sensori (memory sensory), memori jangka pendek (short term memory atau working memori), dan memori jangka panjang (long term memory). Memori seseorang berkaitan dengan informasi yang didapat tersimpan berapa lama, hal inilah yang ditekankan dalam proses pembelajaran. Selain itu (Santrock, 359:2009) mengatakan bahwa memori adalah penyimpanan informasi di setiap waktu, para psikologi pendidikan mempelajari bagaimana informasi pada awalnya ditempatkan atau dikodekan menjadi memori (encoding), bagaimana informasi disimpanan setelah dikodekan (storage), dan bagaimana informasi ditemukan atau dipanggil kembali untuk tujuan tertentu di waktu yang akan datang (retrieval). Jadi memori adalah penyimpanan suatu informasi yang dilakukan ketika anak siap dan berulang-ulang agar terjadi pengkodean untuk kemudian dapat dipanggil kembali. Dalam proses penyampaian informasi tentunya terdapat tahap-tahap yang harus dilakukan agar informasi tersampaikan dalam memori.

Sejalan dengan hal tersebut (Feldman, 349) menyatakan bahwa model pemroses informasi menggambarkan bahwa otak memiliki tiga "gudang" : memori sensorik, memori kerja, dan memori jangka panjang. Masing-masing jenis memori ini memiliki kerangka waktu yang berbeda. (Santrock, 363:2009) menyatakan bahwa memori sensoris (yang berlangsung selama hitungan satu detik sampai beberapa detik), memori jangka pendek (juga disebut sebagai working memori, berlangsung selama kurang lebih 30 detik), dan memori jangka panjang (yang berlangsung sampai seumur hidup). Berbagai bentuk pengalaman yang kita bentuk bisa kita dapat dari indera, perbuatan, dan emosi. Sejalan dengan hal tersebut (Hagwood, 59:2008) mengatakan bahwa setiap memori terfokus secara hati-hati dibentuk melalui Tiga Aturan Hubungan yang Bersifat Dua Arah (Three Reversible Rules of Engagement), yaitu; 1) Sebuah memori terfokus berhubungan dengan indera kita, 2) Sebuah memori terfokus berhubungan dengan emosi kita, 3) Sebuah memori terfokus berhubungan dengan tindakan kita. Oleh karena itu, apa yang kita lihat, kita rasakan, kita kecap dan kita lakukan akan lebih kita ingat daripada apa yang kita bayangkan. Segala sesuatu yang kita alami akan lebih diingat daripada imajinasi atau cerita belaka. Hal tersebut sangat mempengaruhi memori seseorang. 
Kemampuan memori pada anak usia dini adalah suatu kemampuan untuk menyimpanan informasi sebanyak-banyaknya untuk kemudian dikeluarkan kembali (retrieval) dengan recalling, recognition, relearning, dan redintegration. Memori anak usia dini harus diperhatikan melalui tahapan-tahapan yang sesuai dan diukur berdasarkan kemampuan yang dapat dicapainya. Kesimpulan teori kemampuan memori merupakan proses sentral dalam perkembangan kognitif anak yang meliputi penyimpanan informasi terus-menerus mulai dari penerimaan informasi (encoding) melalui indera, emosi serta tindakan, kemudian penyimpanan informasi (storage) yang meliputi pengolahan perhatian, persepsi, latihan, dan mengeluarkan kembali (retrieval).

\section{KONSEP ANGKA}

Anak anak menggunakan angka, yang mencakup tulisan angka Arab, seperti menghitung objek di himpunan, mencipta himpunandengan jumlah objek yang telah tertentu, membandingkan dan mengurutkan himpunan atau angka arab dengan menggunakan makna kardinan (Morrison, 267:2012). Sedangkan menurut Lestari (2011) Untuk mengenalkan konsep angka pada anak usia dini dapat dilakukan melalui tiga tahap, yaitu: 1) membilang, yaitu menyebutkan bilangan berdasarkan urutan, 2) mencocokan setiap angka dengan benda yang sedang dihitung, 3) membandingkan antara kelompok benda satu dengan kelompok benda yang lain untuk mengetahui jumlah benda yang lebih banyak, lebih sedikit, atau sama. Anak-anak mulai dapat mengembangkan pemahaman- nya tentang konsep angka bila mereka diajak menggunakan angka-angka dalam berbagai kegiatan sehari-hari. Misalnya mengajak anak menyanyikan lagu yang memuat angka seperti lagu Satu-satu, meminta tiga anak untuk membantu menata meja makan atau meletakan alat/bahan main. Rahmawati (2013:10) menegaskan bahwa :Pada anak usia dini, anak sudah dapat di ajarkan konsep matematika sederhana misalnya membilang dan mengenal lambang bilangan, karena anak usia dini belum dapat dituntut untuk berfikir secara logis, maka proses pembelajarannya dilakukan dengan cara bermain menggunakan peraga atau benda-benda diskekitarnya. Kesimpulan teori konsep angka merupakan bagian dari matematika, dimana anak memahami tentang bentuk angka, dan bagaimana menyebut angka tersebut.

\section{KONSEP ULAR TANGGA}

Permainan Ular tangga merupakan jenis permainan papan yang didesain khusus untuk anak umur tiga tahun ke atas. Permainan yang dapat dimainkan oleh dua anak atau lebih ini 
dapat memberikan manfaat besar, khususnya anak yang sulit belajar. Berikut ini adalah beberapa definisi permainan ular tangga menurut beberapa ahli ada beberapa definisi permainan ular tangga yang telah dimodifikasi sesuai dengan fungsi dan tujuan permainan tersebut digunakan. (Nurjatmika, 103:2012) mengatakan permainan ular tangga adalah permainan yang menggunakan papan gambar yang bisa disesuaikan sesuai fungsinya, permainan ini bisa dikelompokkan sesuai dengan umur anak ataupun bentuk tampilan gambar, aturan permainannya, setiap pemain dimulai pada bidak yang terdapat dipojok kiri bawah, secara bergiliran melemparkan dadu, kemudian lihat angka berapa yang muncul pada dadu. Bidak dapat berjalan sesuai dengan jumlah mata dadu yang muncul, bila pemain mendarat ujung bawah sebuah tangga, mereka dapat langsung naik ke ujung tangga yang lain, bila mendarat di kotak dengan ular, mereka harus turun kekotak ujung dibawah ular tersebut.

(Husna, 145:2009) mendefinisikan permainan Ular Tangga adalah permainan menggunakan dadu untuk menentukan berapa langkah yang harus dijalani bidak,papan ularnya sendiri berupa gambar kotak-kotak yang terdiri dari 10 baris dan 10 kolom dengan nomor 1-100, serta bergambar ular dan tangga, para pemain diundi untuk menentukan siapa yang jalan pertama kali dan seterusnya, pemain pertama mengocok dan melempar dadu, lalu melangkah pada kotak sesuai jumlah titik pada dadu, jika dadu menunjukkan angka 6 maka pemain tersebut mendapatkan kesempatan untuk menjalankan bidak sebanyak 6 langkah dan mengocok dadu kembali, bidak yang berhenti diekor ular harus turun kekotak yang terdapat kepala ularnya, jika bidak berhenti dibawah tangga maka pemain dapat langsung naik ke kotak tempat ujung tangga berakhir dan pemain yang pertama kali tiba digaris finish adalah pemenangnya. Definisi permainan ular tangga menurut (Mulyani, 121:2013) dalam bukunya 45 permainan tradisional anak Indonesia adalah sarana bermain ini terdiri dari selembar papan atau kertas tebal bergambar kotak-kotak sebanyak 100 buah, dimana terdapat gambar ular tangga dan tangga pada kotak-kotak tertentu, lalu terdapat sebuah tabung atau gelas kecil dari plastik dan dadu kecil berbentuk kotak tapi tumpul pada setiap sudutnya sehingga mudah menggelinding, pada sisi sisi dadu ini terdapat bintik berjumlah satu hingga enam bintik, dadu ini juga terbuat dari plastik, lalu ada lagi sebuah plastik kecil berbentuk kerucut, pemain bisa sendirian, bisa juga dengan 2-3 anak laki-laki ataupun perempuan, cara memainkan bergantian satu persatu anak. (Jamil, 155:2009), mendefinisikan permainan ular tangga 
sedikit berbeda dengan definisi para ahli sebelumnya, karena permainan ini sudah dimodifikasi, dengan mengadopsi permainan ular tangga yang seperti biasa. Permainan ular tangga ini digunakan untuk sarana atau media belajar anak-anak bila benar jawaban, maka bisa naik tangga bila salah maka akan turun tangga seperti ular. Anak-anak harus belajar bekerja sama dengan baik, terutama untuk menjawab soal berupa pengetahuan yang mereka pelajari. Anak-anak juga belajar dan berlatih memahami suatu strategi berpikir yang tepat dan cepat.

(Cahyo, 121:2011) Ular tangga adalah permainan papan untuk anak-anak yang dimainkan oleh dua orang atau lebih. Papan permainan dibagi dalam kotak-kotak kecil dan di beberapa kotak digambar sejumlah tangga dan ular yang menghubungkannya dengan kotak lain. Permainan ini diciptakan pada tahun 1870. Setiap pemain mulai dengan bidaknya di kotak pertama dan secara bergiliran melemparkan dadu, bidak dijalankan sesuai dengan jumlah mata dadu yang muncul, bila pemain mendarat diujung bawah sebuah tangga, mereka dapat langsung pergi keujung tangga yang lain, bila mendarat dikotak dengan ular, mereka harus turun kekotak di ujung bawah ular dan pemenang adalah pemain pertama yang mencapai kotak terakhir, biasanya bila seorang pemain mendapatkan angka enam dari dadu, mereka mendapat giliran sekali lagi, bila tidak maka giliran jatuh ke pemain selanjutnya.

Menurut definisi para pakar diatas maka dapat diambil kesimpulan bahwa permainan ular tangga adalah permainan yang menggunakan papan bergambar berbentuk kotak-kotak bertuliskan angka 1-100, akan tetapi pembuatan bidak bisa disesuaikan sesuai dengan fungsi dan tujuan permainan dan tidak ada aturan yang pasti. Permainan ular tangga ini menggunakan dadu yang mempunyai 6 sisi dan juga bidak untuk dijalankan. Apabila bidak berada di bawah tangga maka bidak bisa naik ke ujung tangga, sedangkan apabila bidak berada di kepala ular maka bidak harus turun menuju ke ekor ular. Apabila dadu menunjukkan angka 6 maka pemain bisa melempar dadu sebanyak 2 kali.

Permainan ular tangga merupakan permainan tradisional Indonesia yang peneliti modifikasi agar anak dapat memulai mengenal angka 1-10 dengan model permainan dan dilakukan dengan bermain. Sehingga anak tidak mudah bosan dan diharapkan dapat meningkatkan kemampuan anak dalam meningkatkan memori untuk konsep angka sehingga dapat dengan mudah anak mengingat. 


\section{METODOLOGI}

Tempat penelitian adalah BKB Mawar Kalibata Jakarta Selatan. Kelompok yang dipilih adalah kelompok A usia 4-5 tahun sebanyak 15 anak, 8 anak perempuan dan 7 anak laki-laki. Waktu Penelitian dilakukan pada bulan Januari 2017- April 2017 dimulai dengan penelitian pra tindakan, penelitan siklus 1 dan siklus 2 serta penyelesaian hasil penelitian.

Metode yang digunakan dalam penelitian ini adalah action research atau penelitian tindakan. Penelitian tindakan adalah penelitian tentang, untuk dan oleh masyarakat atau kelompok sasaran dengan memanfaatkan interaksi, partisipasi, dan kolaborasi anatara peneliti dan kelompok sasaran. Penelitian tindakan adalah sebagai suatu bentuk penelitian yang bersifat reflektif dengan melakukan tindakan-tindakan tertentu agar dapat memperbaiki dan atau meningkatkan praktek-praktek pembelajaran di kelas secara professional. Dalam prakteknya penelitian tindakan menggabungkan tindakan yang bermakna dengan prosedur penelitian. Ini adalah suatu upaya pemecahan suatu masalah sekaligus mencari dukungan ilmiah. Pihak yang terlibat mencoba dengan sadar merumuskan suatu tindakan atau intervensi yang diperhitungkan dapat memecahkan masalah atau memperbaiki situasi kemudian secara cermat mengamati pelaksanaannya untuk memahami tingkat keberhasilannya.

Pada dasarnya penelitian tindakan ini menggunakan prosedur Kemmis dan MC Taggart. Model ini pada hakekatnya berupa perangkat atau untaian-untaian dengan satu perangkat yang terdiri dari empat komponen yang dipandang sebagai suatu siklus spiral dan meliputi tahaptahap: a) perencanaan (planning), b) tindakan (acting), c) pengamatan (observing), d) refleksi (reflecting).(Kusumah, 20:2009). Keempat komponen yang berupa untaian tersebut dipandang sebagai satu siklus. Oleh karena itu, pengertian siklus pada penelitian ini ialah suatu putaran kegiatan yang terdiri dari perencanaan, tindakan, observasi, dan refleksi. Penelitian ini terdiri dari dua siklus, jika siklus I belum berhasil maka diadakan siklus II, begitu sampai dengan penelitian tersebut dinyatakan berhasil.

Analisis data penelitian tindakan secara umum dilakukan dengan mengidentifikasikan dan menyetujui kriteria yang digunakan untuk menerangkan apa yang terjadi atau menunjukkan bahwa perbaikan telah terjadi sehingga dapat membantu penelitian dalam mengembangkan penjelasan dan kejadian atau situasi yang berlangsung dalam kelas penelitian. 
Hopkins dalam Rochiati mengemukakan bahwa ada tiga langkah analisis yang perlu dilakukan di lapangan dan analis ke empat dilakukan setelah penelitian lapangan selesai, langkah-langkah tersebut dilakukan tahap demi tahap, secara sekuensial dengan logis, tahapan kedua akan sangat ditentukan oleh analisis tahapan sebelumnya. Selanjutnya, berbagai kesimpulan diambil dalam tahapan-tahapan tadi, yang digunakan untuk tahapan berikutnya, langkah ketiga adalah bahwa ada beberapa kriteria yang dipakai untuk analisis di lapangan, antara lain pemilihan dan definisi permasalahan konsep, penghitungan frekuensi dan distribusi kejadian atau fenomena, dan dimasukkannya temuan-temuan individual ke dalam kajian yang sedang diteliti. Analisis setelah kegiatan di lapangan adalah bagaimana evidensi dan bukti dalam penelitian ini dipresentasikan (Wiriaatdmadja, 145:2010).

Dalam analisis data penelitian ini menggunakan analisis kualitatif namun dalam melihat pencapaian peningkatan dan penghitungan hasil peneliti menggunakan bantuan data kuantitatif, kemudian kesimpulan diolah kembali menjadi data kualitatif. Berikut ini paparan dari analisis penelitian yang digunakan:

1. Data yang bersifat kualitatif (deskriptif pelaksanaan kegiatan/pembelajaran dari tindakan yang diberikan serta pandangan-pandangan guru), kemudian dianalisis secara induktif dengan langkah (a) Reduksi data yaitu mereduksi data berarti merangkum, memilih halhal pokok, memfokuskan pada hal-hal penting, dicari tema dan polanya dan membuang yang tidak perlu, (b) display data yaitu penyajian data kualitatif yang dapat dilakukan dalam bentuk uraian singkat, bagan, hubungan antar kategori, flowchart dan sejenisnya, c) verifikasi data merupakan penarikan kesimpulan yang dikemukakan pada tahap awal kemudian didukung oleh bukti-bukti yang valid dan konsisten saat penelitian kembali ke lapangan untuk mengumpulkan data, maka kesimpulan yang dikemukakan merupakan kesimpula kredibel.

2. Data yang bersifat kuantitatif berupa analisis statistik deskriptif. Teknik deskriptif untuk menggambarkan karakteristik distribusi skor responden masing-masing penelitian misalnya mencari nilai rerata, porsentase keberhasilan, dan lain-lain (Arikunto, 131:2006)

Analisis data ini dilakukan sebelum, selama, dan sesudah pengumpulan data atau dilakukan dalam satu putaran siklus yang dimulai dari masalah, perencanaan, pelaksanaan tindakan dan observasi, dan evaluasi tindakan. 
Analisis kuantitatif dilakukan untuk melihat perubahan peningkatan kemampuan membaca permulaan anak pada asesmen awal dan asesmen akhir dengan menggunakan prosentase rata-rata setiap aspek kemampuan membaca permulaan. Untuk melihat hasil tindakan yang dilakukan, digunakan perhitungan prosentase menurut Purwanto dengan rumus sebagai berikut (Purwanto, 112:2008).

$$
P=\frac{\Sigma x}{N} \times 100 \%
$$

Keterangan:

$\mathrm{P} \quad=$ Proporsi atau perbandingan antara jumlah sampel dengan kemampuan yang dicapai oleh anak

$\sum \mathrm{x} \quad=$ Jumlah nilai atau skor yang diperoleh subjek

$\mathrm{N} \quad=$ Skor maksimal

\section{HASIL DAN PEMBAHASAN}

Dalam pendahuluan sudah diuraikan bahwa tujuan penelitian ini adalah untuk memahami bagaimana proses pembelajaran untuk meningkatkan kemampuan memori anak pada konsep angka melalui permainan ular tangga pada anak kelompok A di BKB Mawar Kalibata dan untuk mengetahui apakah pembelajaran menggunakan permainan ular tangga ini dapat meningkatkan kemampuan memori anak pada konsep angka.

Untuk menjawab rumusan penelitian tersebut diperlukan adanya analisis dan interprestasi terhadap data pada penelitian ini. Dalam penelitian ini juga diungkapkan keterlaksanaan pembelajaran dengan menggunakan media ular tangga di BKB Mawar Kalibata. Berikut ini akan diuraikan hasil penelitian tindakan Peningkatan Kemampuan Memori Anak pada Konsep Angka Melalui Permainan Ular Tangga di BKB Mawar Kalibata.

\section{a. Tahap Perencanaan}

Pada tahap perencanaan, tindakan yang direncanakan terdiri dari 6 kali pertemuan dengan indikator instrumen yang sama pada siklus I dan siklus II akan tetapi di berikan beberapa kegiatan yang berbeda dengan menggunakan permainan ular tangga supaya pada siklus II ini hasil yang didapatkan dari perlakuan bisa maksimal. 


\section{b. Pelaksanaan Tindakan}

Penelitian Hari- 1

Penelitian dilaksanakan pada tanggal 1 Februari 2018 pukul 09.00-10.00 di BKB Mawar dalam penelitian pertama ini peneliti bersama guru berkolaborasi dalam melakukan penelitian. Kegiatan inti dipertemun 1, anak-anak melakukan kegiatan mengenal angka. Kegiatan berlanjut di teras sekolah, ibu guru memperkenalkan permainan ular tangga kepada anak-anak, dan memberitahukan cara bermain ular tangga. Anak-anak sangat antusias menyimak dan memperhatikan cara bermain yang diperagakan oleh guru. Setelah itu anakanak diminta berkelompok, 1 kelompok terdiri 2 orang. 1 anak berperan sebagai bidak dan 1 anak berperan melempar dadu dan mengambil perintah. Setiap kelompok bergantian melakukan kegiatan bermain ular tangga ini. Kegiatan dipertemuan 1 ini adalah mengenal angka 1-5. Kegiatan berlangsung setiap bermain terdiri dari 2 kelompok, anak melakukan perintah sesuai kartu perintah yang mereka ambil, kartu tersebut dibaca dan anak-anak melakukannya dengan bantuan guru. Di dalam kartu disebutkan untuk perintah mengenal angka, menulis angka, menyebutkan angka 1-5. Di pertemuan ini masih belum dilakukan penilaian sehingga anak masih tahap pengenalan dan belajar.

Penelitian Hari- 2

Penelitian dilaksanakan pada tanggal 2 Februari 2018 pukul 09.00-10.00 di BKB Mawar. Pada pertemuan kedua ini peneliti dan guru mengulang kembali apa yang dikerjakan oleh anak pada pertemuan pertama. Ditambah dengan pengenalan angka 6-10 dengan menggunakan permainan ular tangga dan kartu perintah. Anak memulai dengan senang dan anak dapat mengikuti permainan dengan baik dibimbing oleh guru, karena hari berikutnya anak sudah melakukan.

Penelitian Hari- 3

Penelitian dilaksanakan pada tanggal 3 Februari 2018 pukul 09.00-10.00 di BKB Mawar. Pada pertemuan ketiga ini adalah kegiatan mengulangi dari pertemuan pertama dan kedua. Anak melakukan pengulangan kegiatan dan dilakukan penilaian siklus I untuk diambil kesimpulan apakah diperlukan siklus II dalam penelitian ini. 
Penelitian Hari- 4

Penelitian dilaksanakan pada tanggal 8 Februari 2018 pukul 09.00-10.00 di BKB Mawar. Hari ini akan dilakukan penelitian siklus II, kegiatan yang dilakukan adalah kegiatan yang sama dengan siklus I. Anak mengulang kembali kegiatan mengenal angka 1-10 dengan menggunakan permainan ular tangga. Tetapi untuk kartu perintah lebih ditingkatkan kesulitannya. Anak mengulang-mengulang perintah sampai anak dapat benar benar memahami apa yang diperintahkan. Kegiatan ini diulangi sampe seluruh anak melakukan kegiatan permainan ini.

Penelitian Hari- 5

Penelitian dilaksanakan pada tanggal 9 Februari 2018 pukul 09.00-10.00 di BKB Mawar. Pada hari ini peneliti hanya mengulang kegiatan seperti hari sebelumnya. Kegiatan ini ditujukan untuk membuat anak lebih paham dalam mengingat dan memori anak tersimpan dengan baik terhadap pengenalanan huruf awal.

Penelitian Hari- 6

Penelitian dilaksanakan pada tanggal 10 Februari 2018 pukul 09.00-10.00 di BKB Mawar. Hari ini adalah hari terakhir siklus II, peneliti melakukan penilaian apakah dengan permainan ular tangga ini dapat meningkatkan kemampuan memori anak pada konsep angka. Dalam kegiatan yang dilakukan hampir $85 \%$ anak sudah meningkat dalam konsep angka, sehingga anak mampu dikatakan berhasil melakukan kegiatan ular tangga ini untuk meningkatkan memori.

\section{c. Pengamatan}

Berikut ini adalah hasil kuantitatif dari penelitian pra tindakan, siklus I, siklus II penelitian : 


\section{Tabel 1.Hasil Penelitian}

\begin{tabular}{l|l|l|l|}
\multirow{2}{*}{ Nama } & Pra Tindakan & Siklus I & \multicolumn{1}{l}{ Siklus II } \\
\cline { 2 - 4 } AN & 45 & 78 & 87 \\
\hline AK & 53 & 82 & 88 \\
\hline BR & 67 & 82 & 89 \\
\hline CD & 58 & 77 & 89 \\
\hline EM & 35 & 56 & 84 \\
\hline GA & 66 & 73 & 95 \\
\hline HF & 77 & 84 & 83 \\
\hline ID & 81 & 85 & 90 \\
\hline KW & 72 & 89 & 98 \\
\hline MW & 42 & 64 & 83 \\
\hline NR & 72 & 83 & 90 \\
\hline PY & 59 & 79 & 84 \\
\hline RA & 78 & 84 & 89 \\
\hline SN & 61 & 70 & 86 \\
\hline TP & 59 & 63 & \\
\hline
\end{tabular}

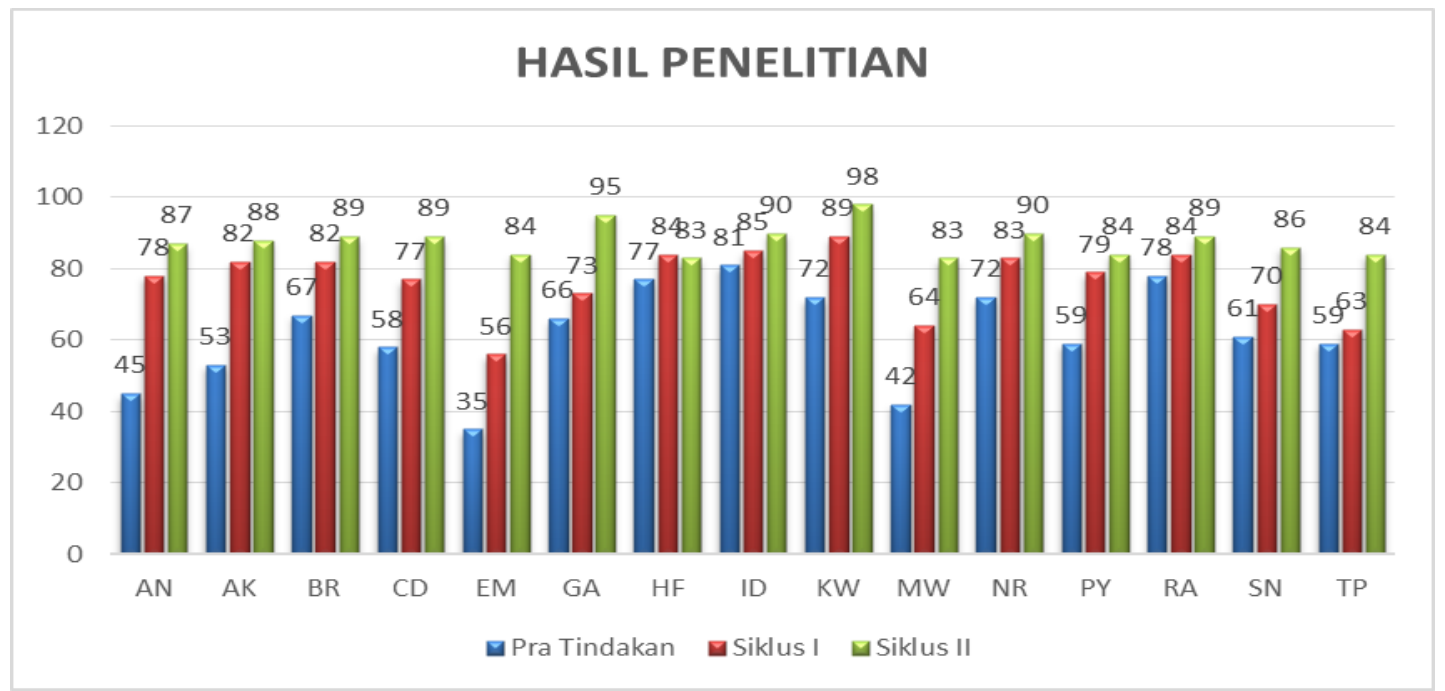

\section{Gambar 2. Grafik Hasil Penelitian}


Dalam tabel dan grafik diatas terlihat tabel yang tejadi peningkatan yang signifikan dari kegiatan pra tindakan, siklus I dan siklus II. Pada kegiatan Pra Tindakan rata-rata nilai adalah $61,66 \%$, pada siklus I rata rata nilai adalah $76,60 \%$, dan pada siklus II meningkat menjadi $87,93 \%$

\section{d. Refleksi}

Refleksi pada siklus ini dilaksanakan untuk melihat hasil dari kegiatan yang dilaksanakan. Peneliti dan kolaborator mengidentifikasi hasil, kekurangan dan kemajuan kegiatan yang dilaksanakan pada kegiatan.

Berdasarkan hasil observasi berlangsung, maka dapat dianalisis sebagai berikut:

1. Kegiatan dan media yang dilaksanakan dan digunakan penelitian sudah dikatakan berhasil, karena kegiatan lebih beragam, beberapa media juga bertambah dan anak-anak bisa melaksanakan kegiatan ini lebih maksimal.

2. Dari catatan wawancara guru dan beberapa anak, mereka mengatakan bahwa permainan ini menyenangkan dan tidak membosankan sehingga bisa efektif untuk meningkatkan memori anak dalam kemampuan konsep angka. Pada umumnya hasil prosentase anak yang pada siklus I belum mendapatkan skor minimal yaitu $80 \%$, pada siklus II beberapa anak tersebut sudah mencapai skor diatas skor minimal tersebut. Sedangkan rata-rata kelas sudah mencapai $85 \%$ sehingga siklus II ini dikatakan berhasil karena sudah mencapai skor kesepakatan peneliti dan kolaborator yaitu $80 \%$ untuk nilai skor individu dan $85 \%$ untuk nilai skor klasikal atau kelompok.

3. Permainan ular tangga untuk meningkatkan memori anak dalam konsep angka ini dapat dikembangkan oleh guru atau peneliti yang lain untuk meningkatkan beberapa aspek yang lainnya, seperti sosial, kerjasama, disiplin, bidang-bidang bahasa lainnya. Karena pada saat perlakuan yang dilakukan dengan menggunakan permainan ular tangga ini beberapa aspek diatas juga muncul pada saat anak melaksanakan kegiatan.

Dari refleksi di atas peneliti dan kolaborator bersepakat untuk menghentikan kegiatan permainan ular tangga ini pada siklus II karena kegiatan ini sudah dikatakan berhasil mencapai skor minimal yang disepakati oleh peneliti dan kolaborator. 


\section{SIMPULAN}

Menjawab pertanyaan dari rumusan masalah pada pendahuluan, dapat diambil kesimpulan dari penelitian adalah sebagai berikut:

1. Proses pembelajaran berawal dari: (a) Guru menyediakan perangkat permainan ular tangga yang digunakan dalam pembelajaran; (b) Guru menunjukkan dan menjelaskan kepada anak-anak alat permainan ular tangga; (c) Guru mempraktekkan permainan ular tangga dan diikuti anak-anak untuk praktek langsung permainan ular tangga; (d) Guru memfokuskan untuk meningkatkan kemampuan mengenal angka 1-10; (e) Guru mengulang permainan ular tangga ini sampai anak memahami dan terjadi peningkatan memori anak dalam konsep angka; (f) Evaluasi dilakukan dengan observasi, pengamatan dan juga beberapa wawancara. Penerapan permainan ular tangga ini dapat meningkatkan kemampuan memori anak dalam konsep angka karena permainan ular tangga ini memiliki ukuran besar untuk alat permainannya, papan ular tangga besar berukuran 1,5x 2,5 meter dan bertuliskan angka. Dadu berukuran $30 \mathrm{~cm}$ setiap sisinya, dan anak sebagai bidak yang berjalan. Selain itu juga terdapat alat penunjang lainnya seperti kartu gambar, kartu angka. Permainan ini juga dilakukan dengan bergerak sehingga anak-anak tidak bosan dan anak-anak bisa bermain seraya belajar juga. Peneliti melihat pada saat permainan ini berlangsung anak-anak sangat antusias dan bersemangat pada saat mereka bermain.

2. Kemampuan peningkatan memori anak dalam konsep angka kelompok A BKB Mawar meningkat setelah menggunakan permainan ular tangga yang dibuktikan dengan peningkatan persentase pada setiap aspek yaitu peningkatan memori konsep angka mencapai $61,66 \%$, setelah dilaksanakan siklus I meningkat menjadi $76,60 \%$ dan pada siklus II meningkat lagi menjadi $87,93 \%$. Selain dari hasil penilaian secara kualitatif, peningkatan memori konsep angka pada anak usia dini dilihat juga dari hasil pengamatan kuantitatif seperti wawancara, pengamatan catatan lapangan, observasi, dan juga dokumentasi. Semua data diolah dan disatukan untuk mengumpulkan bukti bahwa permainan ular tangga ini dapat meningkatkan kemampuan memori anak dalam konsep angka dilihat dari hasil observasi peneliti melihat bahwa anak terlihat perubahan dalam pembelajaran mengenal angka. Setelah diadakan penghitungan skor dan reduksi data 
maka dapat disimpulkan bahwa permainan ular tangga dapat meningkatkan kemampuan memori anak pada konsep angka kelompok A PAUD BKB Mawar Jakarta Selatan.

\section{DAFTAR PUSTAKA}

Sudjana, Nana, 2002, Dasar-dasar Proses Belajar Mengajar, Bandung: Sinar Baru Al Gensindo

Wonk, Willy. dan Andri Hakim. 2010. Dahsyatnya Hipnosis. Jakarta : Visi Media.

Aisyah, Siti dkk. Perkembangan dan Konsep Dasar Pengembangan Anak Usia Dini. Jakarta: Universitas Terbuka, 2011.

Cahyo, Agus N. Gudang Permainan Kreatif Khusus Asah Otak Kiri Anak. Jogjakarta: FlashBooks, 2011.

Feldman, Papalia Olds. Human Development Perkembangan Manusia Edisi 10 Buku 1. Jakarta: Salemba Humanika, 2009.

Jensen, Eric. Brain Based Learning. Yogyakarta: Pustaka Belajar, 2008.

Kusumah, Wijaya. Mengenal Penelitian Tindakan Kelas. Jakarta:Indeks, 2009

M, A. Husna. 100+ Permainan Tradisional Indonesia .Yogyakarta:Andi , 2009.

Madya, Suwarsih. Penelitian Tindakan Action research. Bandung:Alfabeta, 2011.

Morrison, George S. Dasar-Dasar Pendidikan Anak Usia Dini (PAUD). Jakarta: Indeks, 2012

Mulyani, Sri 45. Permainan Tradisional Anak Indonesia .Yogyakarta:Langensari Publishing, 2013.

Mills, Geoffrey E, Action Research a Guide for the Teacher Research. New Jersey:Merrill Prentice Hall, 2003.

Nurjatmika, Yusep. Ragam Aktifitas Harian Untuk TK . Jogjakarta:Diva Pres, 2012.

Rahmawati, Dwi. (2013). Permainan Kreatif Mengenal Angka 1-10. Jakarta : Papas Sinar Sinanti.

Santrock, John W. Psikologi Pendidikan Educational Psychology Edisi 3 Buku 1. Jakarta: Salemba Humanika, 200.

Suharsimi Arikunto, Suhardjono, Supardi, Penelitian Tindakan Kelas, Jakarta: PT. Bumi Aksara, 2006.

Sya’ban Jamil, 101 Games Cerdas dan Kreatif. Jakarta:Penebar Plus, 2009.

Tedjasaputra, Mayke S. Bermain, Mainan dan Permainan untuk Pendidikan Usia Dini, Jakarta:Gramedia, 2001. 